\title{
Celia Britton
}

Language and Literary Form in French Caribbean Writing. Liverpool: Liverpool

University Press, 2014. vii +220 pp. (Cloth $\left.£_{70.00}\right)$

Language and Literary Form in French Caribbean Writing comprises articles, essays, and book chapters written by Celia Britton over twenty years, with reflections on literary criticism and theory that concentrate on language and form. For Britton, it is time to rethink French postcolonial studies, and she stresses a lingering issue, "the colonized subject's difficult relation to the colonial language" (p. 7). Echoing Gayatri Spivak's main concern in Death of a Discipline (2003), she underscores the need to return to basics: focusing on close reading and taking literary form and genre into account. For Britton, this approach fosters new relationships between the textual and the political. The main goal is to go beyond a mere examination of the ways in which postcolonial literature rewrites the British literary canon and to open new perspectives on the theorization of French Caribbean literature. Britton argues that postcolonial writers should not be reduced to mere écrivains engagés, dedicated exclusively to political discourse. Rather, literary creations should also be studied for the topoi and social contexts that they bring to life. Proposing various ways to conceive the political, she integrates discussions of postcolonial theory and (post)structuralist theory, relying more heavily on the latter in her discourse.

The book's first part, "Genre, Intertextuality, Discourse," includes six chapters that cover several French Caribbean writers' relationship to language and form. The first three deal with the exclusive relationship between French Caribbean authors and European audiences and the dangers of exoticism. Chapter 1 explores the misguided attraction for primitivism in essays published in Tropiques in the 1940s, using French surrealism as well as African American literature and European anthropology as literary and ideological backdrops. Chapter 2 concentrates on the notion of auto-exoticism in the late 1950s with Réné Ménil's anticolonial work and between the late 1980 os and the early 1990s with the creolist project of Raphaël Confiant and Patrick Chamoiseau. Chapter 3 focuses on the relationship between French Caribbean writers and their European readership by teasing out the relationship between exoticism, consumerist mentality, consumption, and the commodification of French Caribbean language as an "edible" object. Britton uses scholarship by Graham Huggan and Mikhail Bakhtin to reframe the debates concerning créolité. Departing from exoticism, Chapter 4 probes the intertextuality between French Caribbean and Jewish discourses in their construction of the diaspora and exile in Gisèle Pineau's L'exil selon Julia (1996) and Simone \& André Schwarz-Bart's Un plat de porc aux bananes vertes (1967). Chapter 5 proposes

(C) JACQUELINE COUTI, 2016 | DOI: 10.1163/22134360-09003045

This is an open access article distributed under the terms of the Creative Commons 
that in Traversée de la Mangrove (1989), Maryse Condé reforms realism not in order to reject the realist text as defined by Roland Barthes, but rather to reduce reliance on ideological debates and combat exotic stereotypes. (An appendix provides a 2001 interview with Maryse Condé that expands on some of these issues.) Chapter 6 applies postcolonial feminist theory to Daniel Maximin's L'Ile et une nuit (2002), discussing narrative agency and a feminine voice linked to an empty subjectivity in order to demonstrate that it is closer than traditional postcolonial novels to a Lacanian/Derridean version of poststructuralist models.

The book's second part, "On Édouard Glissant," explores novels and essays that grapple with issues of language and poetics and their connection to realism, narratology, and identity. Here Britton deepens the discussion on the rewriting of "formal characteristics of realists texts" (p. 7) that she began in her chapters on Condé and Maximin. This part, which draws on scholarship by Ferdinand de Saussure, Maurice Merleau-Ponty, Gilles Deleuze, and Félix Guattari among others, is the most theoretical. The first two chapters rethink the difficulty of representing Caribbean history through political discourse. Hence, Chapter 7 probes the characteristics of the discursive structure of Glissant's Le Quatrième siècle (1964). Chapter 8 then shifts the emphasis to the evolution of the collective narrative voice in Malemort (1975), La case du commandeur (1981), and Mahagony (1987). Chapter 9 examines how Tout-Monde (1993) further criticizes monolithic identity and promotes identitarian plurality. Chapter 10 assesses the interaction of language in a globalized world in Glissant's work and his changed perception in the late 1980 s and the early 199os. Finally, Chapter 11 examines the connection between presenting the work of art and the real in Une Nouvelle région du monde: Esthétique I (2006). Britton brings to the fore Glissant's new aesthetic "that covers both literary texts and the visual arts, and which both emerges out of the relationship between artist/writer and landscape and is based on difference" (p. 155).

Britton is persuasive in arguing for the need to reevaluate the study of the formal aspects of literary texts produced in the French Caribbean. As she makes clear, eventually neither (post)structuralist nor postcolonial theory fully does justice to all French Caribbean texts. In concise chapters, the broad corpus she brings together establishes the way in which formal and textual analysis also uncovers the implications of the political.

\section{Jacqueline Couti}

Department of Modern Languages and Literatures, University of Kentucky, Lexington KY 40504, U.S.A. Jacqueline.couti@uky.edu 